\title{
Presence of multidrug resistance (MDR) and extended-spectrum beta- lactamase (ESBL) of Escherichia coli isolated from cloacal swabs of broilers in several wet markets in Surabaya, Indonesia
}

\author{
MUSTOFA HELMI EFFENDI ${ }^{1, \bullet}$, WIWIEK TYASNINGSIH ${ }^{2}$, YEMIMA ANGGUN YURIANTI ${ }^{3}$, \\ JOLA RAHMAHANI ${ }^{2}$, NENNY HARIJANI ${ }^{1}$, HANI PLUMERIASTUTI ${ }^{4}$ \\ ${ }^{1}$ Department of Veterinary Public Health, Faculty of Veterinary Medicine, Universitas Airlangga. Jl. Raya Mulyorejo, Surabaya 60115, East Java, \\ Indonesia. Tel.: +62-31-5992785, 5993016, Fax. +62-31-5993015, `email: mheffendi@yahoo.com \\ ${ }^{2}$ Department of Veterinary Microbiology, Faculty of Veterinary Medicine, Universitas Airlangga. Jl. Raya Mulyorejo, Surabaya 60115, East Java, \\ Indonesia \\ ${ }^{3}$ Faculty of Veterinary Medicine, Universitas Airlangga. Jl. Raya Mulyorejo, Surabaya 60115, East Java, Indonesia \\ ${ }^{4}$ Department of Veterinary Pathology, Faculty of Veterinary Medicine, Universitas Airlangga. J1. Raya Mulyorejo, Surabaya 60115, East Java, Indonesia
}

Manuscript received: 28 November 2020. Revision accepted: 23 December 2020.

\begin{abstract}
Effendi MH, Tyasningsih W, Yurianti YA, Rahmahani J, Harijani N, Plumeriastuti H. 2021. Presence of multidrug resistance $(M D R)$ and extended-spectrum beta-lactamase (ESBL) of Escherichia coli isolated from cloacal swab of broilers in several wet markets in Surabaya, Indonesia. Biodiversitas 22: 304-310. The purpose of this research was to identify multidrug resistance (MDR) and extended-spectrum beta-lactamase (ESBL) of Escherichia coli from cloacal swabs of broiler chicken in several wet markets in Surabaya. This study used 60 broiler chicken samples, with cloacal swab method. The samples were isolated and identified to find Escherichia coli with several procedures, including MacConckey Agar (MCA), Eosin Methylene Blue Agar (EMBA), Gram staining, indole test, Methyl Red-Voges Proskauer (MR-VP), citrate, and Triple Sugar Iron Agar (TSIA). Antibiotic sensitivity test was conducted by using Kirby-Bauer (Disc Diffusion Method) with antibiotics: Aztreonam, Gentamicin, Chloramphenicol, Tetracycline, and Ciprofloxacin. From results, it can be illustrated that the isolates resistant to antibiotic Ciprofloxacin were $67 \%$ and Tetracycline was 65\%. Total 97\% isolates were found sensitive for Aztreonam, 73\% for Chloramphenicol, and 55\% for Gentamicin. Twelve isolates identified for MDR and two were ESBL. It can be explained that broiler chicken from wet market should be considered as a source of transmission for MDR and ESBL of E. coli to the public health.
\end{abstract}

Keywords: Escherichia coli, MDR, ESBL, Broiler chicken, Wet markets, Public health

\section{INTRODUCTION}

The human diseases from food products of animals origin can be categorized as foodborne diseases The diseases caused by consumption of broiler chicken as food is one of them. Broiler chicken production is relatively high because of the high level of consumption, especially in the part of chicken meat. Meat product of animal origin contains antibiotic residues which make these products bacterial resistant. Meat contaminated resistant E. coli bacteria can transfer it from animals to humans via food chain pathway or direct contact. The use of antibiotics in the long term can affect the resistance of bacteria, both pathogens or normal microflora in the body of living things (Effendi et al. 2019, Wibisono et al. 2020).

Poultry can act as an important reservoir of bacterial agents. Infected poultry can be a source of disease transmission. Pathogenic microorganisms can cause infectious disease which is the main cause of death in animals and humans (Suardana et al. 2014). The increase in the incidence of infectious diseases is mainly because of inappropriate use of antibiotics is the most dominant in poultry farms (Wiedosari and Wahyuwardani 2015; Wibisono et al. 2020). The high use of antibiotics can lead to an increase in antibiotic resistance. The combination preparation of amoxicillin and colistin (60.8\%) is most widely used in several farms. The perception of farmers that the use of antibiotics has no side effects and is a cheap effort to prevent disease (Niasono et al. 2019; Masruroh et al. 2016). This ultimately leads to an increase in the factors causing the emergence of antibiotic resistance in poultry as food of animal origin.

A research carried out by Suandy (2011) revealed that the resistance level of $E$. coli isolated from broiler chicken meat from the traditional Bogor market was $80.6 \%$ against Tetracycline, $14.2 \%$ against Gentamicin, and $11.4 \%$ against Chloramphenicol. From these data, it was concluded that the level of resistance of E. coli to some antibiotics was quite high due to their excessive use. Broiler chicken meat isolated in testing by Akmal et al. (2017) showed high resistance levels in the antibiotics Tetracycline, Ciprofloxacin, and Gentamicin.

The selection of appropriate antibiotics based on bacterial resistance patterns is important for the assessment of bacterial resistance factors and controlling the incidence of resistance from bacteria in animal food to humans (Putra et al. 2019; Vasilakopoulou et al. 2020). Aztreonam, Gentamicin, Chloramphenicol, Tetracycline, and 
Ciprofloxacin are broad-spectrum antibiotics from several classes of effective antibiotics and are often used in cases of $E$. coli bacterial infections (Karaman 2015).

This study was conducted to obtain an overview of the profile of antibiotic resistance from broiler chickens related to biosafety based on the high cases of resistance of $E$. coli bacteria in humans that can be transmitted from food products of animal origin. Broiler chickens for research were taken from three wet markets in Surabaya and cloacal swabs were used to collect bacterial samples. The market was chosen because of the high supply of broiler chickens and a large number of purchases by consumers in the market.

\section{MATERIALS AND METHODS}

\section{Samples}

The sample consisted of 60 broilers cloacal swabs were taken from three Surabaya, Indonesia wet markets, i.e. Pucang Market, Keputran Market, and Wonokromo Market.

\section{Isolation and identification}

Sixty samples taken by the cloacal swab method were put into a vacutainer tube containing Buffered Peptone Water (BPW) and put into a cool box. Samples were cultured on Mac Conkey Agar (MCA) media for 24 hours at $37^{\circ} \mathrm{C}$. The bacterial colonies on MCA media were observed for color and texture and processed for identification of $E$. coli (Effendi et al. 2018; Putra et al. 2020).

Colonies suspected of being Escherichia coli bacteria on EMBA media were again stained with Gram stain to confirm the morphology and nature of the bacteria. Separate colonies that had been tested for Gram staining were followed by biochemical IMViC tests (Indol, MR-VP, citrate) and TSIA. E. coli bacteria showed positive indole results and motility on the SIM media. In the Methyl-Red (MR) test, E. coli bacteria showed positive results and Voges-Proskauer (VP) with negative results. In the citrate test, E. coli bacteria showed negative results. TSIA test results showed Acid/Acid results, negative $\mathrm{H}_{2} \mathrm{~S}$, and positive gas (Putra et al. 2019; Kristianingtyas et al. 2020).

\section{Antibiotic sensitivity test}

The suspension E. coli bacterial isolate was made by synchronized with McFarland 0.5 standard and then tested for antibiotic sensitivity using the Kirby-Bauer diffusion method against Aztreonam, Gentamicin, Chloramphenicol, Tetracycline, and Ciprofloxacin antibiotics on Mueller Hinton Agar (MHA) media. For this, the suspension was inoculated on MHA media for $16-18$ hours at $37^{\circ} \mathrm{C}$. Inhibitory zone diameters were measured using a calipers measuring instrument with an accuracy of 0.02 millimeters (mm) and adjusted Clinical and Laboratory Standards Institute (CLSI 2017; Rahmahani et al. 2020).

\section{ESBL confirmation test by DDST}

ESBL producing $E$. coli can be confirmed by using Double Disc Synergy Test (DDST). This confirmation test is to evaluate the presence of a inhibitory zone of ESBL activity with clavulanic acid. This conventional method was carried out by using the Kirby-Bauer disk diffusion method on Mueller - Hinton agar (Merck, Germany). The DDST confirmation test used an antibiotic (Oxoid, England) disc Amoxicillin-clavulanate $30 \mu \mathrm{g}$, Cefotaxim $30 \mu \mathrm{g}$, and Ceftazidime $30 \mu \mathrm{g}$. The culture was incubated at temperatures of $35-37{ }^{\circ} \mathrm{C}$ for $18-24$ hours. Evaluation results after incubation showed the presence of inhibitory zones that appeared in the cup were measured according to the Clinical and Laboratory Standards Institute (Effendi et al. 2018; Wibisono et al. 2020).

\section{RESULTS AND DISCUSSION}

\section{Antibiotic sensitivity test}

The results of isolation and identification of $E$. coli that grew with red, convex characteristics and clear boundaries on MCA media, were followed by biochemical IMViC tests. Positive results of IMViC test continued with antibiotic sensitivity testing as shown in Figure 1 and Table 1.

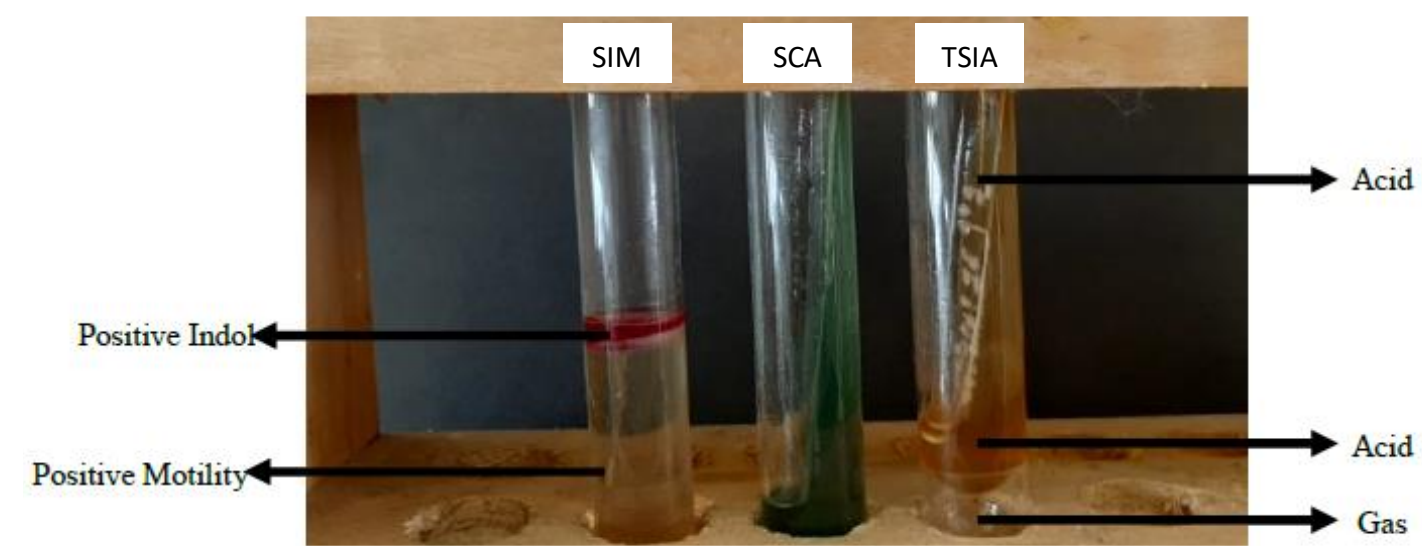

Figure 1. The results of identification of Escherichia coli bacteria on Sulfide Indole Motility (SIM), Simons Citrate Agar (SCA), and Triple Sugar Iron Agar (TSIA) media 
Tabel 1. Results of antibiotic sensitivity test for 60 isolates of $E$. coli

\begin{tabular}{lcccccc}
\hline \multirow{2}{*}{ Antibiotics } & \multicolumn{2}{c}{$\begin{array}{c}\text { Sensitive } \\
\text { samples }\end{array}$} & \multicolumn{2}{c}{$\begin{array}{c}\text { Intermediate } \\
\text { samples }\end{array}$} & \multicolumn{2}{c}{ Resistant } \\
& samples \\
& N & \% & N & \% & N & \% \\
\hline Aztreonam & 58 & 97 & 0 & 0 & 2 & 3 \\
Gentamicin & 33 & 55 & 5 & 8 & 22 & 37 \\
Chloramphenicol & 44 & 73 & 2 & 3 & 14 & 23 \\
Tetracycline & 18 & 30 & 3 & 5 & 39 & 65 \\
Ciprofloxacin & 12 & 20 & 8 & 13 & 40 & 67 \\
\hline
\end{tabular}

Results of antibiotic sensitivity test for 60 isolates of $E$. coli illustrated that 2 samples $(3 \%)$ were resistant to Aztreonam $30 \mu \mathrm{m}$ antibiotic with inhibition zone $\leq 17 \mathrm{~mm}$ and 58 sensitive samples with inhibition zone $\geq 21 \mathrm{~mm}$. Chloramphenicol $30 \mu \mathrm{m}$ antibiotics contained 14 samples $(23 \%)$ resistant to inhibition zones $\leq 12 \mathrm{~mm}$ and 44 samples $(73 \%)$ sensitive to inhibition zones $\geq 18 \mathrm{~mm}$. Tetracycline $30 \mu \mathrm{m}$ antibiotics showed that 39 samples $(65 \%)$ were resistant with $11 \mathrm{~mm}$ inhibition zone and 18 samples $(30 \%)$ were sensitive with $15 \mathrm{~mm}$ inhibition zone, as shown in Table 2 .

Bacterial resistance is the nature of the disruption of bacterial cell life to antibiotics. Resistance arises due to excessive use of antibiotics that poses long enough impacts on humans (Nahar et al. 2014; Wibisono et al. 2020). Antibiotic sensitivity test was conducted by using the Kirby-Bauer method. The media was incubated at $37^{\circ} \mathrm{C}$ for \pm 24 hours and the inhibition zone was measured using a caliper that was used to determine resistance, intermediate and sensitivity compared to the 2017 CLSI standard.

Antibiotic sensitivity test results of $60 \mathrm{E}$. coli bacterial isolates showed $67 \%$ resistance towards Ciprofloxacin and $65 \%$ towards Tetracycline resistant. Isolates were found sensitive to antibiotics Aztreonam (97\%), Chloramphenicol (73\%), and Gentamicin (55\%). The results of the sensitivity test of $E$. coli bacteria towards Ciprofloxacin revealed that $67 \%$ of the isolates were found resistant. These results are in accordance with the research of Baharutan et al. (2015) which showed that $62.5 \%$ of $E$. coli isolates were resistant to Ciprofloxacin. Ciprofloxacin antibiotics belong to the class of fluoroquinolones which work to influence DNA Gyrase acids in bacteria, thus inhibiting DNA synthesis. The sensitivity test of $E$. coli bacteria to ciprofloxacin cannot inhibit the existing DNA Gyrase enzyme, causing antibiotic resistance. Ciprofloxacin resistance is the result of a mutation of the gyrA subunit from Gyrase that reduces the ability of antibiotics to bind to bacteria.

The results of the sensitivity test of E. coli bacteria towards Tetracycline showed the resistance of $65 \%$ isolates. A study carried out on patients at Fatmawati Hospital revealed that Tetracycline antibiotics have a high level of resistance against E. coli (Refdanita et al. 2004). Suandy (2011) showed the pattern of Tetracycline resistance and observed this antibiotic highly resistant to $E$. coli bacteria. Tetracycline antibiotics inhibit bacteria by inhibiting the process of the $30 \mathrm{~S}$ ribosome of prokaryotic by binding to aminoacyl-tRNA.
Table 2. Antimicrobial Resistance Profile of Escherichia coli isolated from Broiler Chicken of several wet markets in Surabaya

\begin{tabular}{|c|c|c|c|c|c|}
\hline \multirow[b]{2}{*}{ Sample code } & \multicolumn{5}{|c|}{ Antibiotics (mm) } \\
\hline & 志 & 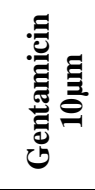 & 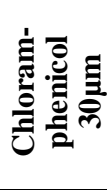 & 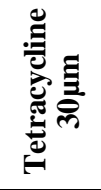 & 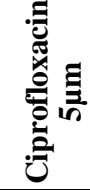 \\
\hline BPS 1 & 33.43 & NCZ & 26.00 & 21.24 & 7.08 \\
\hline BPS 2 & 32.64 & 17.43 & 25.56 & $\mathrm{NCZ}$ & 8.42 \\
\hline BPS 3 & 32.46 & $\mathrm{NCZ}$ & 22.60 & 18.18 & 6.63 \\
\hline BPS 4 & 29.52 & 17.60 & 21.78 & $\mathrm{NCZ}$ & $\mathrm{NCZ}$ \\
\hline BPS 5 & 33.54 & NCZ & 22.72 & 21.25 & 7.24 \\
\hline BPS 6 & 33.36 & 9.94 & NCZ & 9.82 & 13.74 \\
\hline BPS 7 & 35.74 & NCZ & 25.62 & 20.18 & 9.68 \\
\hline BPS 8 & 34.34 & 8.46 & 24.84 & 14.00 & 24.86 \\
\hline BPS 9 & 24.31 & 13.86 & 28.18 & 9.88 & 28.14 \\
\hline BPS 10 & 28.86 & 11.96 & 20.14 & 5.93 & 18.36 \\
\hline BPS 11 & 34.48 & NCZ & 27.32 & 7.74 & 26.88 \\
\hline BPS 12 & 30.82 & 16.36 & NCZ & 6.36 & 21.98 \\
\hline BPS 13 & 32.31 & 16.39 & 8.06 & 7.44 & 9.36 \\
\hline BPS 14 & 15.72 & 6.26 & 28.04 & 20.28 & 29.52 \\
\hline BPS 15 & 15.58 & NCZ & 31.86 & 31.98 & 26.06 \\
\hline BPS 16 & 31.78 & NCZ & 29.18 & 12.68 & 11.66 \\
\hline BPS 17 & 30.62 & NCZ & 23.56 & NCZ & 17.86 \\
\hline BPS 18 & 35.58 & NCZ & 24.88 & 22.60 & 9.88 \\
\hline BPS 19 & 36.36 & 23.18 & 26.26 & 15.80 & $\mathrm{NCZ}$ \\
\hline BPS 20 & 24.64 & 15.54 & 19.98 & 7.12 & NCZ \\
\hline BKS 1 & 18.02 & 18.38 & 24.82 & 8.82 & 17.60 \\
\hline BKS 2 & 34.68 & NCZ & NCZ & NCZ & 10.18 \\
\hline BKS 3 & 32.04 & 20.70 & 6.46 & 10.76 & 12.02 \\
\hline BKS 4 & 30.46 & 8.44 & 24.14 & 10.38 & 10.06 \\
\hline BKS 5 & 29.66 & 14.46 & 24.42 & 22.80 & 9.50 \\
\hline BKS 6 & 28.24 & 17.82 & 6.94 & 6.86 & 8.74 \\
\hline BKS 7 & 30.00 & 20.74 & 23.58 & 13.48 & 24.24 \\
\hline BKS 8 & 31.76 & 8.82 & 24.78 & 19.92 & 13.84 \\
\hline BKS 9 & 34.26 & 19.60 & 22.52 & 11.80 & 17.24 \\
\hline BKS 10 & 34.18 & 18.18 & 23.52 & 12.44 & 5.00 \\
\hline BKS 11 & 26.94 & 17.76 & 23.08 & 6.46 & 22.98 \\
\hline BKS 12 & 31.80 & 17.28 & 8.00 & 17.82 & 22.62 \\
\hline BKS 13 & 26.84 & NCZ & 20.40 & 15.82 & 8.04 \\
\hline BKS 14 & 29.68 & 17.78 & 18.02 & 7.74 & 17.80 \\
\hline BKS 15 & 28.00 & 16.88 & 21.62 & 6.90 & 17.36 \\
\hline BKS 16 & 30.66 & NCZ & 25.44 & 8.10 & 7.20 \\
\hline BKS 17 & 33.16 & NCZ & 23.66 & 21.34 & 7.80 \\
\hline BKS 18 & 31.14 & 20.68 & 20.10 & 6.92 & 7.96 \\
\hline BKS 19 & 30.52 & 17.96 & 24.62 & 8.14 & 19.66 \\
\hline BKS 20 & 30.96 & 19.86 & 20.22 & NCZ & 8.66 \\
\hline BWS 1 & 32.64 & NCZ & 24.74 & 16.06 & $\mathrm{NCZ}$ \\
\hline BWS 2 & 26.94 & 16.08 & 16.56 & 5.82 & 16.68 \\
\hline BWS 3 & 30.58 & 16.34 & 20.58 & 10.78 & NCZ \\
\hline BWS 4 & 33.86 & $\mathrm{NCZ}$ & 25.50 & 8.84 & 24.42 \\
\hline BWS 5 & 30.1 & 12.38 & NCZ & 6.60 & 13.64 \\
\hline BWS 6 & 36.72 & 16.94 & $\mathrm{NCZ}$ & 12.30 & $\mathrm{NCZ}$ \\
\hline BWS 7 & 29.98 & 16.60 & 19.78 & 15.22 & 31.06 \\
\hline BWS 8 & 30.98 & 17.66 & NCZ & NCZ & 8.74 \\
\hline BWS 9 & 30.52 & 19.82 & 21.90 & 9.32 & NCZ \\
\hline BWS10 & 33.76 & 17.30 & NCZ & NCZ & $\mathrm{NCZ}$ \\
\hline BWS 11 & 24.18 & 15.98 & 9.96 & NCZ & 23.46 \\
\hline BWS 12 & 26.60 & 13.52 & 21.88 & NCZ & 10.44 \\
\hline BWS 13 & 33.96 & 9.84 & $\mathrm{NCZ}$ & NCZ & 14.66 \\
\hline BWS 14 & 29.84 & 14.44 & NCZ & 8.48 & 6.26 \\
\hline BWS 15 & 28.10 & 15.34 & 19.2 & NCZ & 8.96 \\
\hline BWS 16 & 30.22 & 16.22 & 21.64 & 7.92 & 10.04 \\
\hline BWS 17 & 29.78 & 16.58 & 17.34 & 6.92 & NCZ \\
\hline BWS 18 & 26.64 & 16.28 & 21.20 & NCZ & 9.88 \\
\hline BWS 19 & 27.50 & 15.68 & 21.44 & 8.10 & $\mathrm{NCZ}$ \\
\hline BWS 20 & 29.40 & 15.96 & 19.80 & 8.76 & $\mathrm{NCZ}$ \\
\hline
\end{tabular}

Note: NCZ: No clear zone, BPS: Samples from wet market of Pucang, BKS: Samples from wet market of Keputran, BWS: Samples from wet market of Wonokromo, $\square$ : MDR samples (twelve isolates), $\square$ : ESBL samples (two isolates) 
High levels of resistance to Tetracycline antibiotics can be caused by people often consuming animal food that contains lots of antibiotic residues. The occurrence of tetracycline resistance is due to the transfer of plasmids from resistant bacteria to sensitive bacteria and occurs when bacteria that were initially sensitive are exposed to antibiotic exposure. This antibiotic is often used by the community and as an additive to animal feed as a growth trigger. This is one of the causes of antibiotic resistance in Indonesia (Wibisono et al. 2020).

The sensitivity of bacteria to Aztreonam antibiotic is only 3\% and 97\% sensitive. Research conducted by Anggraini et al. in patients at Arifin Achmad Hospital in Pekanbaru that the sensitivity pattern of E. coli bacteria to aztreonam was $0 \%$ which showed that Aztreonam antibiotics were sensitive to E. coli bacteria (Anggraini et al. 2018). This is confirmed by research on isolates from cow feces that E. coli is sensitive to aztreonam antibiotics by $100 \%$ (Normaliska et al. 2019). Aztreonam works by inhibiting bacterial cell wall synthesis to overcome severe infections by aerobic Gram-negative bacteria. The aztreonam antibiotic spectrum is similar to aminoglycosides, so Aztreonam is an alternative to aminoglycosides, specifically for Gram-negative bacterial infections.

The sensitivity of E. coli bacteria to chloramphenicol antibiotics was $23 \%$ while $73 \%$ sensitive. A study conducted by Susanto (2014) stated that E. coli bacteria isolated from local chickens showed $2.6 \%$ resistance against Chloramphenicol. Chloramphenicol is an antibiotic that is prohibited from being used on farms, so resistance occurs due to the illegal use of antibiotics through feed or drinking water (Susanto 2014). Chloramphenicol is a strong inhibitor of protein synthesis in bacteria. Blocking the attachment of amino acids to the newly arisen peptide chain in the $50 \mathrm{~S}$ unit of the ribosome, by interfering with the action of peptidyl transferase. Chloramphenicol resistance occurs due to destruction of the drug by an enzyme that is controlled by plasmids.

The pattern of antibiotic sensitivity of $E$. coli bacteria was $37 \%$ against Gentamicin and 55\% sensitive. According to Katarnida et al. (2013) in the culture of pediatric patients that Gentamycin is still said to be sensitive to $E$. coli by
$87.5 \%$. Research was also carried out on broiler chicken meat isolates that which stated that $E$. coli bacteria were resistant to antibiotic Gentamycin by $12.5 \%$ and $62.5 \%$ were said to be sensitive (Barus et al. 2013). Gentamicin is an aminoglycoside class of antibiotics that have two or more amino groups that are bound to the benzene group and are bacteriosides.

The results of $E$. coli bacterial profile to antibiotics were found to be resistant such as Ciprofloxacin and Tetracycline. E. coli bacteria resistant to antibiotics can transfer genetic factors to humans through the food chain or direct contact. The use of antibiotics in animals contributes to the occurrence of foodborne bacterial resistance in humans and animals (Pitout and Laupland 2008; Widodo et al. 2020).

Multidrug-resistant (MDR) commonly denotes the resistance of bacteria/microbes of three or more antimicrobial classes (Magiorakos et al. 2012), as shown in Fig. 2. One method that is often used by various researchers to characterize organisms as MDR is based on in vitro antimicrobial susceptibility test results, when researchers tested resistance to multiple antimicrobial agents, classes or subclasses of antimicrobial agents (Okonko et al. 2009). An overview of this variability of definitions is given in a comprehensive review of MDR by Falagas et al. (2006), which is used as a reference by some researchers, as shown in table 2. The most common definitions used to determine the MDR of Gram-positive and Gram-negative bacteria that are resistant to three or more classes of antimicrobials (Exner et al. 2017).

In this study, ESBL-producing E. coli were obtained from cloacal swab samples, as shown in table 2 and figure 3 , which showed that transmission of $E$. coli produced in the environment in poultry farms (Kwoji et al. 2019). In the production of food-producing animals, high concentrations of microorganisms in the air often occur in the environment in cages (Gao et al. 2015; Shoaib et al. 2016). The concentration of microorganisms is closely related to environmental quality. A bad environment can benefit the spread of ESBL-producing E. coli. These microbes in such an environment can survive in the form of aerosols for a long time in the air and transmit with airflow (Brower et al. 2017).

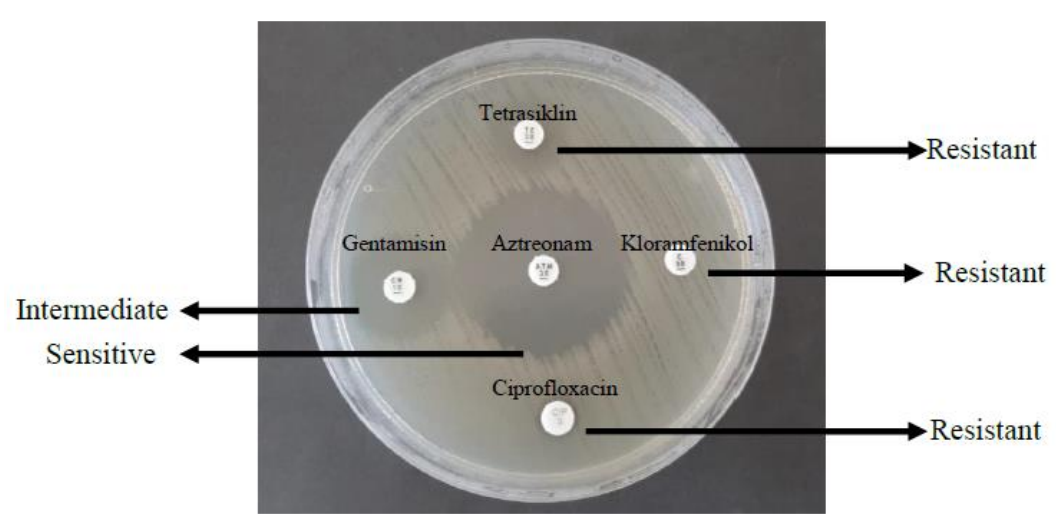

Figure2. MDR of E. coli from Antibiotic Sensitivity test 


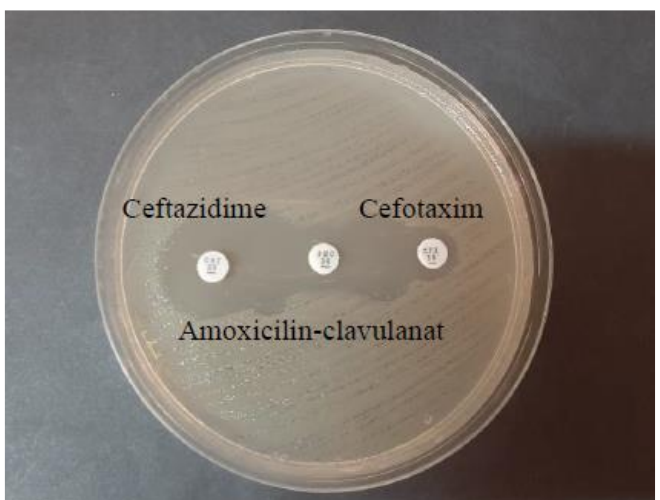

Figure 3. Extended Spectrum Beta-Lactamase (ESBL) producing E. coli by DDST

Previous studies have shown the spread of ESBLproducing $E$. coli from the surrounding area (Niasono et al. 2018). The human population can be exposed to antimicrobial resistant bacteria through encounter interactions with poultry sold in wet markets, which are the source of the presence of MDR and ESBL bacteria. This requires humans to be careful of poultry that can spread these isolates. However, more research is needed to understand how persistence and spread can be minimized (McEwen and FedorkaCray 2002).

In conclusion, this study confirmed that $E$. coli were found $100 \%$ from broiler chicken swabs. The isolates were resistant to Ciprofloxacin antibiotics by (67\%), Tetracycline (65\%), Gentamicin (37\%), Chloramphenicol (23\%), and Aztreonam (3\%). The study identified twelve isolates for MDR and two for ESBL. It can be concluded that broiler chicken from wet market should be considered as a source of transmission for MDR and ESBL of $E$. coli to the public health.

\section{ACKNOWLEDGEMENTS}

This study was supported in part with the Penelitian Hibah Mandat Funding from Airlangga University, Indonesia in fiscal year 2019.

\section{REFERENCES}

Akmal M, Rastina, Harris A, Ismail, Darniati, Masyita D. 2017. Escherichia coli resistance to antibiotics from broiler chicken meat in Rukoh Market. JIMVET 1 (3): 492-498.

Anggraini D, Uswathun HS, Savira M, Fauzia AD, Irawan D, Ruza PR 2018. Prevalence and Sensitivity Pattern of ESBL-Producing Enterobacteriaceae in Arifin Achmad Regional Hospital Pekanbaru. Jurnal Kedokteran Brawijaya 30 (1): 47-52.

Baharutan KN, Fatimawali, Wullur A. 2015. Bacterial sensitivity tes isolated from sputum patients with chronic bronchitis patients undergoing outpatient at Prof. RSUP Dr. R.D. Kandou Manado against Antibiotics Ampicillin, Erythromycin, and Ciprofloxacin. Pharmacon 4 (4): 139-146.

Barus DO, Gelgel KTP, Suarjana IGK. 2013. Sensitivity Test of Escherichia coli bacteria from broilers against Doxycycline,
Gentamicin, and Tiamfenikol antibiotics. Indonesia Medicus Veterinus 2 (5): 538-545.

Brower CH, Mandal S, Hayer S, Sran M, Zehra A, Patel SJ, Kaur R, Chatterjee L, Mishra S, Das BR, Singh P, Singh R, Gill JPS, and Laxminarayan. 2017. The prevalence of extended-spectrum betalactamase-producing multidrug-resistant Escherichia coli in poultry chickens and variation according to farming practices in Punjab, India. Environ Health Perspect 125: 7.

CLSI. 2017. Performance standards for antimicrobial susceptibility testing. 27th ed. CLSI supplement M100. Clinical and Laboratory Standards Institute, Wayne, PA, USA.

Effendi MH, Bintari IG, Aksono EB, Hermawan IP. 2018. Detection of blatem gene of Klebsiella pneumoniae isolated from swab of foodproducing animals in East Java. Trop Anim Sci J 41 (3): 174-178.

Effendi MH, Harijani N, Yanestria SM. Hastutiek P. 2018. Identification of shiga toxin-producing Escherichia coli in raw milk samples from dairy cows in Surabaya, Indonesia. Philippine J Vet Med 55: 109-114.

Effendi MH, Harijani N, Budiarto, Triningtya NP, Tyasningsih W, and Plumeriastuti H. 2019. Prevalence of pathogenic Escherichia coli isolated from subclinical mastitis in East Java Province, Indonesia. Indian Vet J 2019;96(03): 22-25.

Exner M, Bhattacharya S, Christiansen B, Gebel J, Goroncy-Bermes P, Hartemann P, Heeg P, Ilschner C, Kramer A, Larson E, Merkens W, Mielke M, Oltmanns, Ross B, Rotter M, Schmithausen RM, Sonntag H, and Trautmann M. 2017. Antibiotic resistance: what is so special about multidrug-resistant gram-negative bacteria? GMS Hyg Infect Control 12: 5 .

Falagas, M.E., Koletsi, P.K., Bliziotis, I.A. 2006. The diversity of definitions of multidrug-resistant (MDR) and pan drug-resistant (PDR) Acinetobacter baumannii and Pseudomonas aeruginosa. J Med Microbiol 55: 1619-1629.

Gao L, Tan Y, Zhang X, Hu J, Miao Z. 2015. Emissions of Escherichia coli carrying extended-spectrum $\beta$-lactamase resistance from pig farms to the surrounding environment. Intl $\mathrm{J}$ Environ Res Public Health 12: 4203-4213.

Karaman R. 2015. Commonly Used Drugs-Uses, Side Effects, Bioavailability \& Approaches to Improve it. In: Pharmacology Research, Safety Testing and Regulation. Edition: 1. Publisher: Nova Science Publishers, Inc., NY, USA.

Katarnida SS, Karyanti MR, Oman DM, Katar Y. 2013. Patterns of bacterial sensitivity and use of antibiotics. Sari Pediatri 15 (2): 122126.

Kristianingtyas L, Effendi MH, Tyasningsih W, Kurniawan F. 2020. Genetic identification of blactx-M Gene and blatem gene on Extended Spectrum Beta-Lactamase (ESBL) producing Escherichia coli from dogs. Indian Vet J 97 (1): 17-21

Kwoji ID, Musa JA, Daniel N, Mohzo DL, Bitrus AA. 2019. Extendedspectrum beta-lactamase-producing Escherichia coli in chickens from small-scale (backyard) poultry farms in Maiduguri, Nigeria. Intl of One Health 5: 26-30.

Magiorakos AP, Srinivasan A, Carey RB, Carmeli Y, Falagas ME, Giske CG, Harbarth S, Hindler JF, Kahlmeter G, Olsson-Liljequist B, Paterson DL, Rice LB, Stelling J, Struelens MJ, Vatopoulos A, Weber JT, Monnet DL. 2012. Multidrug-resistant, extensively drug-resistant and pandrug-resistant bacteria: an international expert proposal for interim standard definitions for acquired resistance. Clin Microbiol Infect 18: 268-281.

Masruroh CA, Sudarwanto MB, and Latif H. 2016. The occurrence of extended-spectrum B-Lactamase-producing Escherichia coli from broiler feces in Bogor. Jurnal Sains Veteriner 34: 42-49. [Indonesian]

McEwen SA and FedorkaCray PJ. 2002. Antimicrobial use and resistance in animals. Clinical infectious diseases 34 Suppl 3: 93-106.

Nahar A, Siddiquee M, Nahar S, Anwar KS, Ali SI, Islam S. 2014. Multidrug-resistant Proteus Mirabilis isolated from chicken droppings in commercial poultry farms: Bio-security concern and emerging public health threat in Bangladesh. J Biosaf Health Educat 2: 2. DOI: $10.4172 / 2332-0893.1000120$

Niasono AB, Latif H, Purnawarman T. 2019. Antibiotic Resistance to Escherichia coli Bacteria Isolated from Broiler Farms in Subang Regency, West Java. J Vet 20 (2): 187-195.

Okonko IO, Soleye FA, Amusan TA, Ogun AA, Ogunnusi TA, Ejembi J. 2009. Incidence of multi-drug resistance (MDR) organisms in Abeokuta, Southwestern Nigeria. Global J Pharmacol 3: 69-80. 
Pitout JD, and Laupland KB. 2008. Extended-spectrum beta-lactamaseproducing Enterobacteriaceae: an emerging public-health concern. Lancet Infect Dis 8 (3): 159-66.

Putra, A.R. Effendi, M.H. Koesdarto, S. Suwarno, S. Tyasningsih, W. and Estoepangestie, A.T. 2020. Detection of the extended-spectrum $\beta$ lactamase produced by Escherichia coli from dairy cows by using the Vitek-2 method in Tulungagung regency, Indonesia. Iraqi J Vet Sci 34 (1): 203-207.

Putra ARS, Effendi MH, Koesdarto S, Tyasningsih W. 2019. Molecular identification of Extended-Spectrum Beta-Lactamase (ESBL) Producing Escherichia coli isolated from dairy cows in East Java Province, Indonesia. Indian Vet J 96 (10): 26-30.

Rahmahani J, Salamah, Mufasirin, Tyasningsih W, Effendi MH. 2020. Antimicrobial resistance profile of Escherichia coli from cloacal swab of domestic chicken in Surabaya Traditional Market. Biochem Cell Arch 20 (1): 2993-2997.

Refdanita R, Maksum A, Endang P. 2004. Pattern of germ sensitivity to antibiotics in Intensive Care Room Jakarta Fatmawati Hospital 2001 2002. Makara, Kesehatan 8 (2): 41-48. [Indonesian]

Shoaib M, Kamboh AA, Sajid A, Mughal GA, Leghari RA, Malhi KK, Bughio SUD, Ali A, Alam S, Khan S, Ali S. 2016. Prevalence of extended-spectrum beta-lactamase producing Enterobacteriaceae in commercial broilers and backyard chickens. Adv Anim Vet Sci 4: 209-214.

Suandy I. 2011. Antimicrobial resistance in Escherichia coli isolated from commercial broiler farms in Bogor District, West Java [Thesis]. Chiang Mai University, Chiang Mai, Thailand.

Suardana IW, Utama IH, Ayu P, Putriningsih S, Rudyanto D. 2014 Antibiotic Sensitivity Test of Escherichia coli O157: H7 isolate from chicken feces. Buletin Veteriner Udayana. 6 (1): 19-27.
Susanto. 2014. Escherichia coli which are Resistant to Antibiotics Isolated from Broilers and Local Chickens in Bogor District. [Thesis]. Institut Pertanian Bogor, Bogor. [Indonesian]

Vasilakopoulou A, Karakosta P, Vourli S, Tarpatzi A, Varda P, Kostoula M, Antoniadou A, Pournaras S. 2020. Gastrointestinal carriage of vancomycin-resistant Enterococci and Carbapenem-resistant gramnegative bacteria in an endemic setting: prevalence, risk factors, and outcomes. Front Public Health 8: 55. DOI: 10.3389/fpubh.2020.00055

Wiedosari E, Wahyuwardani S. 2015. Case study of broiler chicken disease in Sukabumi and Bogor Districts. J Kedokteran Hewan Indon J Vet Sci 9 (1): 9-13.

Wibisono FJ. Sumiarto B, Untari T, Effendi MH, Permatasari DA, Witaningrum AM. 2020. The presence of Extended-Spectrum BetaLactamase (ESBL) producing Escherichia coli on layer chicken farms in Blitar Area, Indonesia. Biodiversitas 21 (6): 2667-2671.

Wibisono FJ, Sumiarto B, Untari T, Effendi MH, Permatasari DA, Witaningrum AM. 2020. CTX gene of Extended-Spectrum BetaLactamase (ESBL) producing Escherichia coli on broilers in Blitar, Indonesia. Sys Rev Pharm 11 (7): 396-403.

Wibisono FJ, Sumiarto B, Untari T, Effendi MH, Permatasari DA, Witaningrum AM. 2020. Short Communication: Pattern of antibiotic resistance on extended-spectrum beta-lactamases genes producing Escherichia coli on laying hens in Blitar, Indonesia. Biodiversitas, 21 (10): 4631-4635.

Wibisono FM, Wibisono FJ, Effendi MH, Plumeriastuti H, Hidayatullah AR, Hartadi EB, Sofiana ED. 2020. A review of salmonellosis on poultry farms: public health importance. Sys Rev Pharm 11 (9): 481486.

Widodo A, Effendi MH, Khairullah AR. 2020. Extended-spectrum betalactamase (ESBL)-producing Escherichia coli from livestock. Sys Rev Pharm 11 (7): 382-392. 